\title{
PENERAPAN METODE TOPSIS UNTUK SISTEM PENDUKUNG KEPUTUSAN PENENTUAN KELUARGA MISKIN PADA DESA PANCA KARSA II
}

\author{
Irvan Muzakkir \\ Irvanmuzakkir32@gmail.com \\ Universitas Ichsan Gorontalo
}

\begin{abstract}
Abstrak
Menentukan keluarga miskin adalah salah satu upaya pemerintah untuk melakukan intervensi pembangunan dalam bentuk bantuan terhadap keluarga miskin. Tepat sasaran adalah suatu keharusan sehingga benar-benar dapat berdaya guna bagi yang membutuhkan. Perkembangan penduduk Desa Panca Karsa II rata-rata $2 \%$ pertahun, sedangkan angka kelahiran dan kematian ratarata $1 \%$ pertahun. Mayoritas mata pencaharian penduduk adalah petani dan buruh tani. Hal ini disebabkan karena sudah turun temurun dan juga minimnya tingkat pendidikan. Model yang digunakan dalam sistem pendukung keputusan ini adalah FMADM dengan menggunakan Metode TOPSIS. Metode TOPSIS tersebut, diharapkan penilaian akan lebih tepat karena didasarkan pada nilai kriteria dan bobot yang sudah ditentukan sehingga akan mendapatkan hasil yang lebih akurat. Untuk itu peneliti mencoba membantu permasalahan tersebut di atas dengan membuatkan suatu sistem pendukung keputusan menggunakan Bahasa Pemrograman PHP dengan Database MySQL, sehingga Penerapan Metode TOPSIS untuk sistem ini dapat memberikan hasil yang maksimal dalam hal pengambilan keputusan.
\end{abstract}

Kata Kunci: Keluarga Miskin, FMADM,TOPSIS

\section{Pendahuluan}

Kemiskinan adalah kondisi sosial ekonomi warga masyarakat yang tidak mempunyai kemampuan dalam memenuhi kebutuhan pokok yang layak bagi kemanusiaan. Kemiskinan merupakan masalah global yang sering dihubungkan dengan kebutuhan, kesulitan, dan kekurangan di berbagai keadaan hidup. Penyebab kemiskinan sangat banyak, sehingga untuk memotret sebuah kemiskinan bukan sebuah hal yang mudah. Menentukan keluarga miskin adalah salah satu upaya pemerintah untuk melakukan intervensi pembangunan dalam bentuk bantuan terhadap keluarga miskin. Tepat sasaran adalah suatu keharusan sehingga benar-benar dapat berdaya guna bagi yang membutuhkan. [1]

Perkembangan penduduk Desa Panca Karsa II rata-rata 2\% pertahun, sedangkan angka kelahiran dan kematian rata-rata $1 \%$ pertahun. Mayoritas mata pencaharian penduduk adalah petani dan buruh tani. Hal ini disebabkan karena sudah turun temurun sejak dulu bahwa masyarakat adalah petani dan juga minimnya tingkat pendidikan menyebabkan masyarakat tidak punya keahlian lain selain menjadi petani dan buruh tani. (Rencana Pembangunan Jangka Menengah Desa Panca Karsa II). Jumlah penduduk di Desa Panca Karsa II sebanyak 1126 jiwa dengan jumlah KK sebanyak 384 jiwa. Jumlah Keluarga Miskin terdiri dari 77 jiwa dan KK kategori miskin sekali sebanyak 30 jiwa. [2]

Identifikasi masalah dan sumber masalah yang ada dalam pembahasan ini adalah menyangkut masalah penentuan keluarga miskin karena Kemiskinan merupakan permasalahan yang sulit untuk ditangani. Untuk itu diperlukan kriteria untuk menentukan apakah suatu keluarga itu termasuk miskin atau tidak. Selanjutnya, Penentuan keluarga miskin merupakan acuan penting dalam berbagai macam Pemberian bantuan seperti bantuan Raskin, Kartu Indonesia Pintar, Kartu Indonesia Sehat dan bantuan lainnya. Pemberian bantuan tidak tepat sasaran membuat masyarakat yang miskin akan menjadi sangat miskin. Oleh karena itu perlu dirancang sebuah Sistem Pendukung Keputusan Penentuan Keluarga Miskin Pada Desa Panca Karsa II.

Dalam penelitian Zenna Atmaja dkk dalam Jurnal TIKomSiN [3], SPK penentu keluarga miskin ini diharapkan dapat dikembangkan dengan melakukan modifikasi dan penambahan beberapa kriteria dan subkriteria yang lebih lengkap, serta digabungkan menggunakan algoritma lain selain metode (AHP) diharapkan memperoleh perhitungan yang lebih tepat dan akurat. Dalam aplikasi AHP ini jika kriteria semakin banyak maka semakin sulit untuk menentukan dan mengambil keputusan ketika melakukan evaluasi perbandingan pasangan antar kriteria tersebut oleh karena itu perlu dibuat pengelompokan kriteria untuk membatasi kriteria yang banyak. 
Penentuan kriteria-kriteria keluarga miskin diperlukan sebuah sistem informasi yang baik untuk mencegah kesalahan-kesalahan dan kecurangan-kecurangan yang dilakukan oleh pihak-pihak tertentu, dalam hal ini digunakan sistem pendukung keputusan (SPK). Sistem pendukung keputusan (SPK) adalah bagian dari Sistem Informasi berbasis komputer, termasuk sistem berbasis pengetahuan (manajemen pengetahuan) yang dipakai untuk mendukung pengambilan keputusan. Metode yang digunakan dalam sistem pendukung keputusan ini adalah Metode TOPSIS yang menggunakan prinsip bahwa alternatif yang terpilih harus mempunyai jarak terdekat dari solusi ideal positif dan terjauh dari solusi ideal negatif dari sudut pandang geometris dengan menggunakan jarak Euclidean untuk menentukan kedekatan relatif dari suatu alternatif dengan solusi optimal. Berdasarkan perbandingan terhadap jarak relatifnya, susunan prioritas alternatif bisa dicapai.[5]

Untuk itu peneliti mencoba membantu permasalahan tersebut di atas dengan membuatkan suatu sistem pendukung keputusan dengan menggunakan PHP dengan Database MySQL, untuk membuatkan sebuah sistem pendukung keputusan baru yang berbasis komputerisasi yang merupakan salah satu alternatif yang baik dengan mengedepankan efektifitas dan efisien dalam Penentuan Keluarga Miskin. Oleh karena itu Penelitian ini akan merancang sistem dengan judul "Sistem Pendukung Keputusan Penentuan Keluarga Miskin Menggunakan Metode TOPSIS Pada Desa Panca Karsa II".

\section{Metode}

\section{MADM (Multiple Attribute Decision Making)}

MADM adalah salah satu metode yang digunakan untuk mencari alternatif optimal dari sejumlah alternatif dengan kriteria-kriteria tertentu. Inti dari Multiple Attribute Decision Making (MADM) adalah menentukan nilai bobot untuk setiap atribut/kriteria, yang kemudian dilanjutkan dengan proses perankingan yang akan menyeleksi alternatif yang sudah diberikan. Pada dasarnya, ada 3 (tiga) pendekatan untuk mencari nilai bobot atribut, yaitu pendekatan subyektif, pendekatan obyektif dan pendekatan integrasi antara subyektif \& obyektif. Masing-masing pendekatan memiliki kelebihan dan kelemahan. Pada pendekatan subyektif, nilai bobot ditentukan berdasarkan subyektifitas dari para pengambil keputusan, sehingga beberapa faktor dalam proses perankingan alternatif bisa ditentukan secara bebas. Sedangkan pada pendekatan obyektif, nilai bobot dihitung secara matematis sehingga mengabaikan subyektifitas dari pengambil keputusan [5]

\section{TOPSIS (Technique For Order Preference by Similarity to Ideal Solution)}

TOPSIS adalah salah satu metode pengambilan keputusan multikriteria atau alternative pilihan yang merupakan alternative yang mempunyai jarak terkecil dari solusi ideal positif dan jarak terbesar dari solusi ideal negatif dari sudut pandang geometris dengan menggunakan jarak Euclidean. Namun, alternatif yang mempunyai jarak terkecil dari solusi ideal positif, tidak harus mempunyai jarak terbesar dari solusi ideal negatif. Maka dari itu, TOPSIS mempetimbangkan keduanya, jarak terhadap solusi ideal positif dan jarak terhadap solusi ideal negatif secara bersamaan. Solusi optimal dalam metode TOPSIS didapat dengan menentukan kedekatan relatif suatu altenatif terhadap solusi ideal positif. TOPSIS akan merangking alternative berdasarkan prioritas nilai kedekatan relatif suatu alternative terhadap solusi ideal positif. Alternatif-alternatif yang telah dirangking kemudian dijadikan sebagai referensi bagi pengambil keputusan untuk memilih solusi terbaik yang diinginkan. [5]

\section{Kegunaan Metode TOPSIS}

TOPSIS telah digunakan dalam banyak aplikasi termasuk keputusan investasi keuangan, perbandingan performansi dari perusahaan, pebandingan dalam suatu industri khusus, pemilihan sistem operasi, evaluasi pelanggan, dan perancangan robot

\section{Langkah Penyelesaian}

Dalam penelitian ini menggunakan metode TOPSIS. Adapun langkah-langkahnya adalah:

1. Membangun sebuah matriks keputusan.

Matriks keputusan $\mathrm{X}$ mengacu terhadap $\mathrm{m}$ alternatif yang akan dievaluasi berdasarkan $\mathrm{n}$ kriteria. Matriks keputusan $\mathrm{X}$ dapat dilihat sebagai berikut :

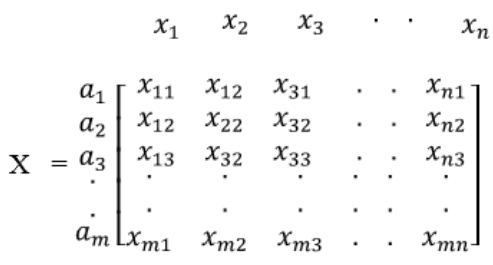


keterangan:

$a_{i}=(i=1,2,3, \ldots, m)$ adalah alternatif-alternatif yang mungkin,

$x_{j}=(j=1,2,3, \ldots, n)$ adalah atribut dimana performansi alternatif diukur,

$x_{i j}$ adalah performansi alternatif $a_{i}$ dengan acuan atribut $x_{j}$

2. Membuat matriks keputusan yang ternormalisasi.

Persamaan yang digunakan untuk mentransformasikan setiap elemen $x \mathrm{ij}$

3. Membuat matriks keputusan yang ternormalisasi terbobot

4. Menentukan Matriks solusi ideal positif dan solusi ideal negative.

5. Menghitung separasi

6. Menghitung Kedekatan terhadap solusi ideal positif

7. Merangking alternatif

Alternatif diurutkan dari nilai $\mathrm{C}^{+}$terbesar ke nilai terkecil. Alternatif dengan nilai $\mathrm{C}^{+}$terbesar merupakan solusi terbaik.

Adapun Kriteria Keluarga Miskin Menurut Dinas Sosial Kabupaten Pohuwato Tahun 2016 [6] adalah sebagai berikut :

Tabel 1. Kriteria KK Miskin

\begin{tabular}{|c|c|c|}
\hline No & Variabel & Kriteria Rumah Tangga Miskin (RTM) Sasaran \\
\hline 1 & Luas Bangunan Tempat Tinggal & Kurang dari $8 \mathrm{M} 2$ perorang \\
\hline 2 & Jenis Lantai bangunan tinggal & Tanah/bamboo/kayu/murahan \\
\hline 3 & Jenis dinding tempat tinggal & $\begin{array}{l}\text { Bambu/rumbia/kayu berkualitas rendah tembok } \\
\text { tanpa plester }\end{array}$ \\
\hline 4 & Fasilitas buang air besar & Tidak punya/sama-sama rumah tangga lain \\
\hline 5 & Sumber penerangan rumah & Bukan listrik \\
\hline 6 & Sumber air minum & Sumur/mata air tidak terlindung/air hujan \\
\hline 7 & Bahan memasak unt & akar/arang/minyak tanah \\
\hline 8 & Konsumsi daging/susu/ayam permi & Tidak pernah mengkonsumsi/1 kali perminggu \\
\hline 9 & $\begin{array}{l}\text { Pembelian pakaian baru untuk setiap } \\
\text { anggota rumah tangga dalam setahun }\end{array}$ & Tidak pernah membeli/1 kali pertahun \\
\hline 10 & $\begin{array}{l}\begin{array}{l}\text { Makanan setiap hari untuk setiap } \\
\text { anggota keluarga }\end{array} \\
\end{array}$ & Hanya 1 kali/2 kali makan sehari \\
\hline 11 & $\begin{array}{lll}\begin{array}{l}\text { Kemampuan } \\
\text { kepuskesmas/poliklinik }\end{array} & \text { berobat } \\
\end{array}$ & Tidak mampu membayar untuk berobat \\
\hline 12 & $\begin{array}{l}\text { Lapangan pekerjaan utama kepala } \\
\text { rumah tangga }\end{array}$ & $\begin{array}{l}\text { Petani dengan luas tanah } 0,5 \mathrm{Ha} / \mathrm{buruh} \text { tani, } \\
\text { nelayan, buruh bangunan, buruh perkebunan dan } \\
\text { lainnya dengan pendapatan dibawah Rp. } 600.000 \\
\text { perbulan }\end{array}$ \\
\hline 13 & 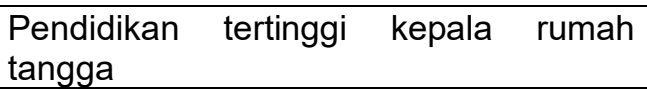 & Tidak sekolah/tidak tamat SD/hanya SD \\
\hline 14 & Pemilik asset & $\begin{array}{l}\text { Tidak punya tabungan/barang yang mudah dijual } \\
\text { dengan nilai minimal Rp. } 500.000 \text { seperti sepeda } \\
\text { motor barang modal lain }\end{array}$ \\
\hline
\end{tabular}

Sumber : Dinas Sosial Kabupaten Pohuwato (2016)

\section{Hasil dan Pembahasan}

\subsection{Langkah-Langkah Menjalankan Sistem}

Untuk menjalankan program cukup dengan mengaktifkan Xampp, membuka browser dan memanggil website Penentuan Keluarga Miskin

\section{Tampilan Halaman Login}

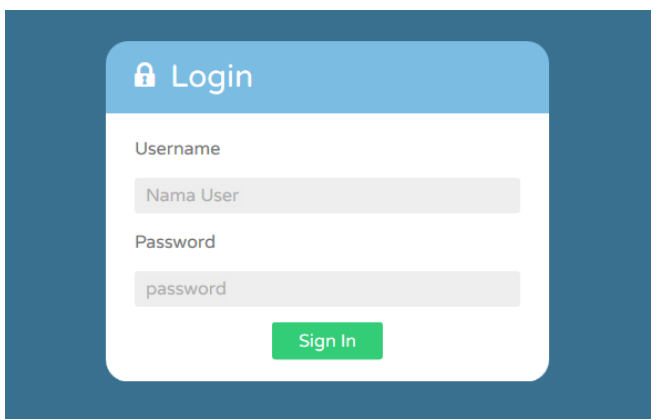

Gambar 1. Halaman Login 
Pada tampilan halaman login ini, user menginput username dan password untuk masuk ke halaman Sistem Pendukung Keputusan Penentuan Keluarga Miskin pada Desa Panca Karsa II. Apabila salah maka akan tampil pesan kesalahan input Username dan password pada layar, kemudian ulangi lagi.

\section{Tampilan Halaman Menu Utama}
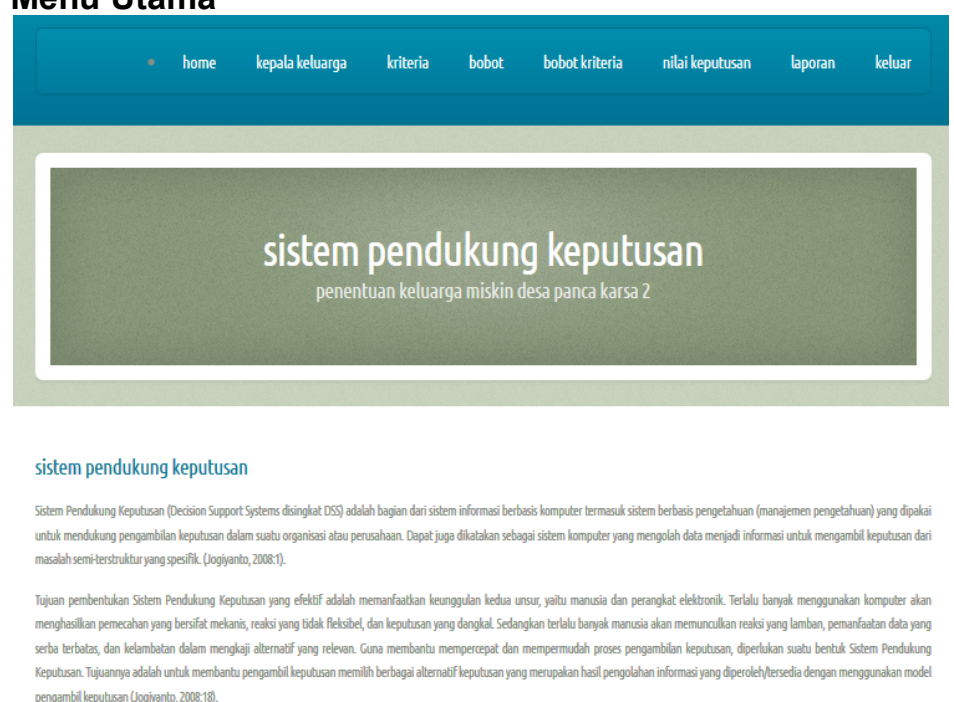

Gambar 2. Tampilan Halaman Menu Utama

Halaman ini berfungsi untuk menampilkan seluruh menu utama yang terdapat Sistem Pendukungan Keputusan Penentuan Keluarga Miskin dengan Metode TOPSIS pada Desa Panca Karsa II. Form ini terdiri atas menu-menu yang terdapat pada lajur atas, yang digunakan menginput seluruh data-data yang diajukan. Halaman menu utama ini terdiri atas halaman Home, Penerima, Kriteria, Bobot, Bobot Kriteria, Nilai Keputusan dan Keluar. Selengkapnya adalah sebagai berikut

\section{Tampilan Menu Utama}

a. Tampilan Entry Data Alternatif/Kepala Keluarga
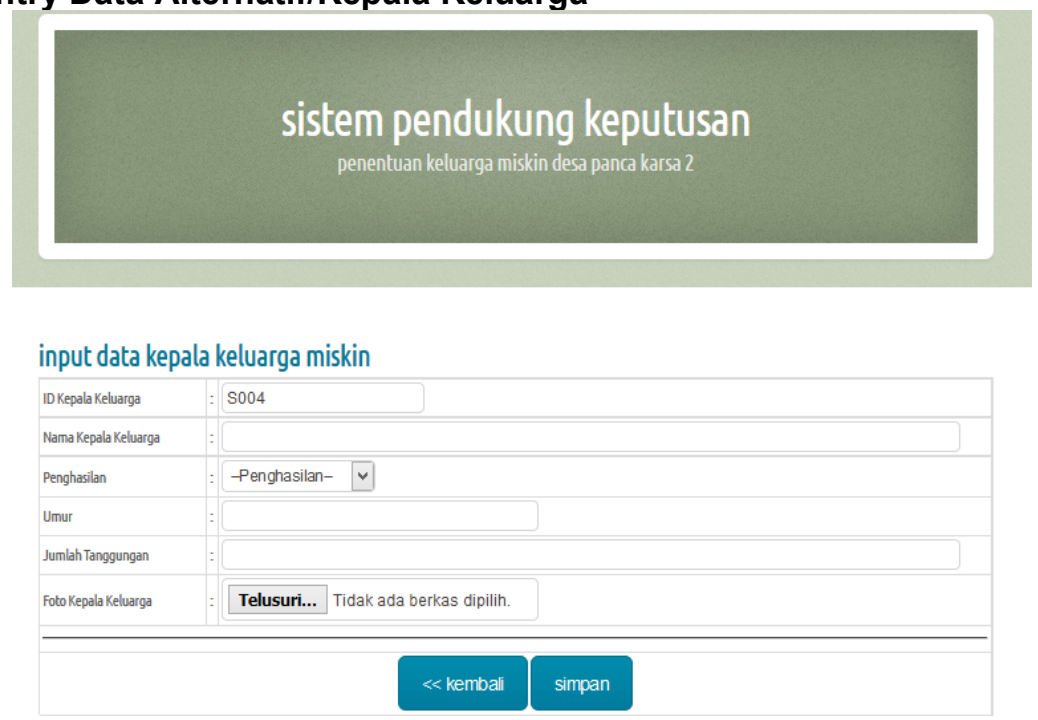

Gambar 3. Entry Data Alternatif

Pada form ini digunakan untuk memasukkan data alternatif/data penduduk yang telah didata dan termasuk warga Desa Panca Karsa II.

\section{b. Tampilan Entry Data Kriteria}




\section{sistem pendukung keputusan}

penentuan keluarga miskin desa panca karsa 2

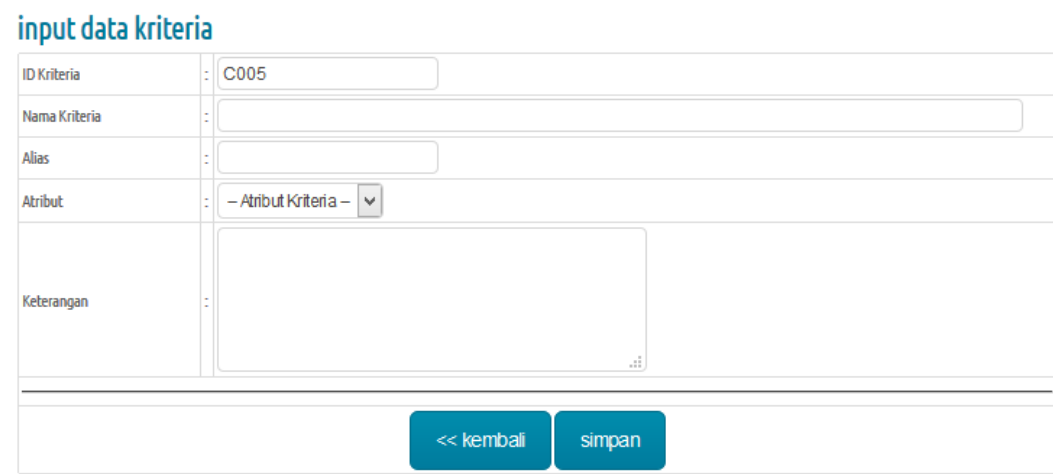

Gambar 4. Entry Data Kriteria

Form ini digunakan untuk menginput data-data kriteria yang akan digunakan dalam Penentuan Keluarga Miskin pada Desa Panca Karsa II. Untuk menginput data pilih tombol tambah kriteria, kemudian isi data kriteria. Setelah data-data sudah terisi lengkap selanjutnya klik simpan untuk menyimpannya dalam sistem. Apabila ingin keluar dari form, klik tombol kembali.

\section{c. Tampilan Entry Data Bobot}

\section{sistem pendukung keputusan}

penentuan keluarga miskin desa panca karsa 2

\section{input data bobot}

\begin{tabular}{|l|l|l|}
\hline ID Bobot & : B006 \\
\hline Nama Bobot & $:$ & \\
\hline Nilai Bobot & & \\
\hline & & \\
\hline & & \\
\hline & & \\
\hline
\end{tabular}

Gambar 5. Entry Data Bobot

Form ini digunakan untuk menginput data-data bobot yang akan digunakan dalam Penentuan Keluarga Miskin pada Desa Panca Karsa II. Untuk menginput data pilih tombol tambah data, kemudian isi data bobot. Setelah data-data sudah terisi lengkap selanjutnya klik simpan untuk menyimpannya dalam sistem. Apabila ingin keluar dari form, klik tombol kembali.

\section{Tampilan Proses}

\section{a. Tampilan Bobot Kriteria}




\section{sistem pendukung keputusan}

\begin{tabular}{|c|c|c|c|}
\hline 01 & Kondisi Tempat Tinggal (BENEFT) & [B004] Tinggi & $v$ \\
\hline 02 & Penyediaan Kebutuhan Seharihari (COST) & [B005] Sangat Tinggi & $v$ \\
\hline 03 & Pendapatan Kepala Keluarga (COST) & [B005] Sangat Tinggi & $\checkmark$ \\
\hline \multirow[t]{2}{*}{04} & Pendidikan Terakhir (BENEFT) & [B003] Cukup & $\checkmark$ \\
\hline & & impan & \\
\hline
\end{tabular}

Gambar 6.Penentuan Bobot Kriteria

Pada form ini digunakan untuk menentukan Bobot Kriteria Penentuan Keluarga Miskin berdasarkan penilaian yang terlebih dahulu diinputkan. Untuk menilai setiap masyarakat terlebih dahulu isi data alternatif, kemudian isi kriteria dan bobot.

\section{b. Tampilan Nilai Keputusan}

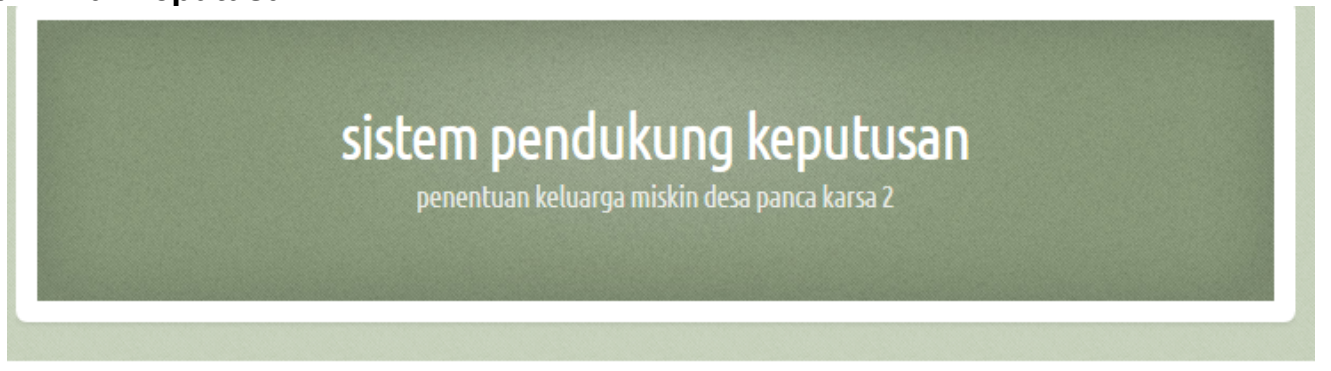

nilai keputusan

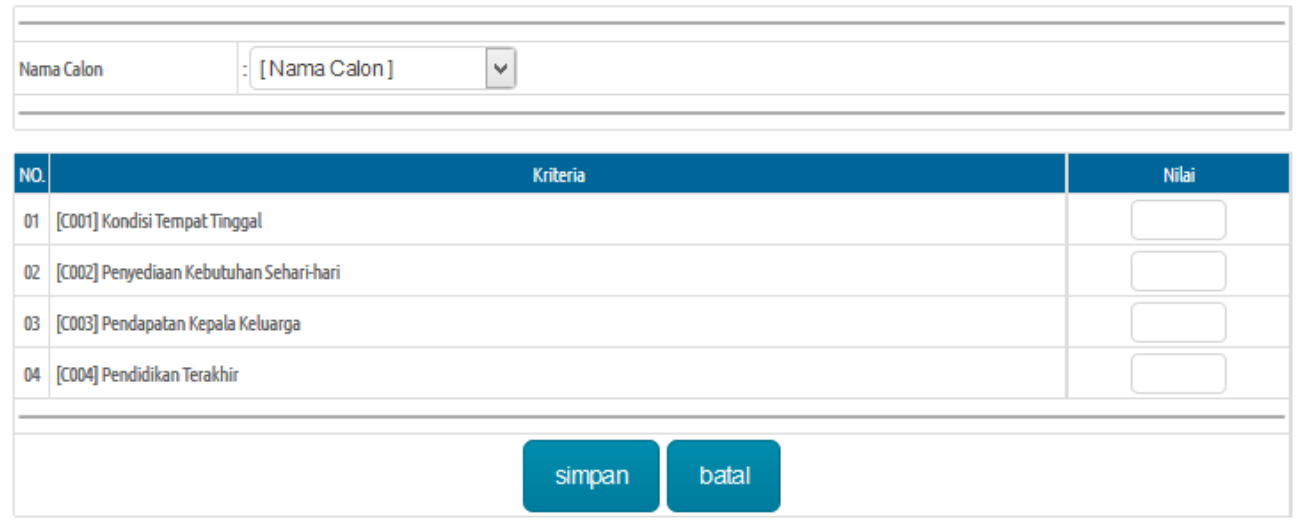

Gambar 7.Nilai Alternatif

Pada form ini digunakan untuk Penentukan Nilai Keputusan Penentuan Keluarga Miskin berdasarkan penilaian yang terlebih dahulu diinputkan. Untuk menilai setiap masyarakat terlebih dahulu isi data alternatif, kemudian isi kriteria, bobot dan bobot kriteria. 
Tampilan Menu Laporan

a. Tampilan Laporan Hasil Analisa TOPSIS

Hasil Analisa

\begin{tabular}{|l|l|l|l|l|l|}
\hline No. & Nama Calon Penerima & $\begin{array}{c}\text { Kondisi Tempat } \\
\text { Tinggal }\end{array}$ & $\begin{array}{c}\text { Penyediaan } \\
\text { Kebutuhan Sehari-hari }\end{array}$ & $\begin{array}{c}\text { Pendapatan Kepala } \\
\text { Keluarga }\end{array}$ & Pendidikan Terakhir \\
\hline 01 & MUh. Yusuf Adam & 85 & 75 & 75 & 75 \\
\hline 02 & husain kono & 75 & 85 & 75 & 85 \\
\hline 03 & Abidin Labaku & 65 & 80 & 70 & 60 \\
\hline
\end{tabular}

Matriksternormalisasi, $\mathrm{R}$

\begin{tabular}{|l|c|l|l|l|}
\hline \multicolumn{1}{|c|}{ Nama Calon Penerima } & $\begin{array}{c}\text { Kondisi Tempat } \\
\text { Tinggal }\end{array}$ & $\begin{array}{c}\text { Penyediaan } \\
\text { Kebutuhan Sehari-hari }\end{array}$ & $\begin{array}{c}\text { Pendapatan Kepala } \\
\text { Keluarga }\end{array}$ & Pendidikan Terakhir \\
\hline MUh. YusufAdam & 0.65048692202437 & 0.54056247761734 & 0.59016710652348 & 0.584776088168909 \\
\hline husain Kono & 0.57395904884504 & 0.61263747463298 & 0.59016710652348 & 0.66272899924763 \\
\hline Abidin Labaku & 0.4974311756657 & 0.57659997612516 & 0.55082263275524 & 0.46780870535127 \\
\hline
\end{tabular}

Matriks ternormalisasi terbobot, $Y$

\begin{tabular}{|l|l|l|l|l|}
\hline \multicolumn{1}{|c|}{ Nama Calon Penerima } & $\begin{array}{c}\text { Kondisi Tempat } \\
\text { Tinggal }\end{array}$ & $\begin{array}{c}\text { Penyediaan } \\
\text { Kebutuhan Sehari-hari }\end{array}$ & $\begin{array}{c}\text { Pendapatan Kepala } \\
\text { Keluarga }\end{array}$ & Pendidikan Terakhir \\
\hline MUh. Yusuf Adam & 2.6019476880975 & 2.7028123880867 & 2.9508355326174 & 1.7542826450673 \\
\hline husain Kono & 2.2958361953801 & 3.0631873731649 & 2.9508355326174 Activdi:288818699774429 \\
\hline Abidin Labaku & 1.9897247026628 & 2.8829998806258 & 2.7541131637762 Go to 51.4034261160538 Win \\
\hline
\end{tabular}

Solusi Ideal Positif (A+)

$Y 1+=\max \{2.6019476880975 ; 2.2958361953801 ; 1.9897247026628 ;\}=2.6019476880975$

$\mathrm{Y} 2+_{+}=\min \{2.7028123880867 ; 3.0631873731649 ; 2.8829998806258 ;\}=2.7028123880867$

$Y_{3+}=\min \{2.9508355326174 ; 2.9508355326174 ; 2.7541131637762 ;\}=2.7541131637762$

$\mathrm{Y}_{+}+=\max \{1.7542826450673 ; 1.9881869977429 ; 1.4034261160538 ;\}=1.9881869977429$

$A+=\{2.6019476880975 ; 2.7028123880867 ; 2.7541131637762 ; 1.9881869977429 ;\}$

Solusi Ideal Negatif (A-)

Y1- $=\min \{2.6019476880975 ; 2.2958361953801 ; 1.9897247026628 ;\}=1.9897247026628$

$Y 2-=\max \{2.7028123880867 ; 3.0631873731649 ; 2.8829998806258 ;\}=3.0631873731649$

Y3- $=\max \{2.9508355326174 ; 2.9508355326174 ; 2.7541131637762 ;\}=2.9508355326174$

$Y 4=\min \{1.7542826450673 ; 1.9881869977429 ; 1.4034261160538 ;\}=1.4034261160538$

$A-=\{1.9897247026628 ; 3.0631873731649 ; 2.9508355326174 ; 1.4034261160538 ;\}$

Jarak antara nilai terbobot setiap alternatif terhadap solusi ideal positif, Si+

$\mathrm{D} 1+=0.3056320281042$

$\mathrm{D} 2+=0.51212700206712$

D3+ $=0.8655806173407$

Jarak antara nilai terbobot setiap alternatif terhadap solusi ideal negatif, Si-
D1- $=0.79233037157241$
$D 2-=0.66003752524189$
D3- $=0.26677185546832$

Kedekatan setiap alternatif terhadap solusi ideal dihitung sebagai berikut

$\mathrm{V} 1=$

0.79233037157241

$=0.72163707227659$

$0.3056320281042+0.79233037157241$

$\mathrm{V} 2=$

0.66003752524189

$=0.56309290194711$

$0.51212700206712+0.66003752524189$

V3 $=$

0.26677185546832

$=0.23559082695032$

$0.8655806173407+0.26677185546832$

Gambar 8. Hasil Analisa 


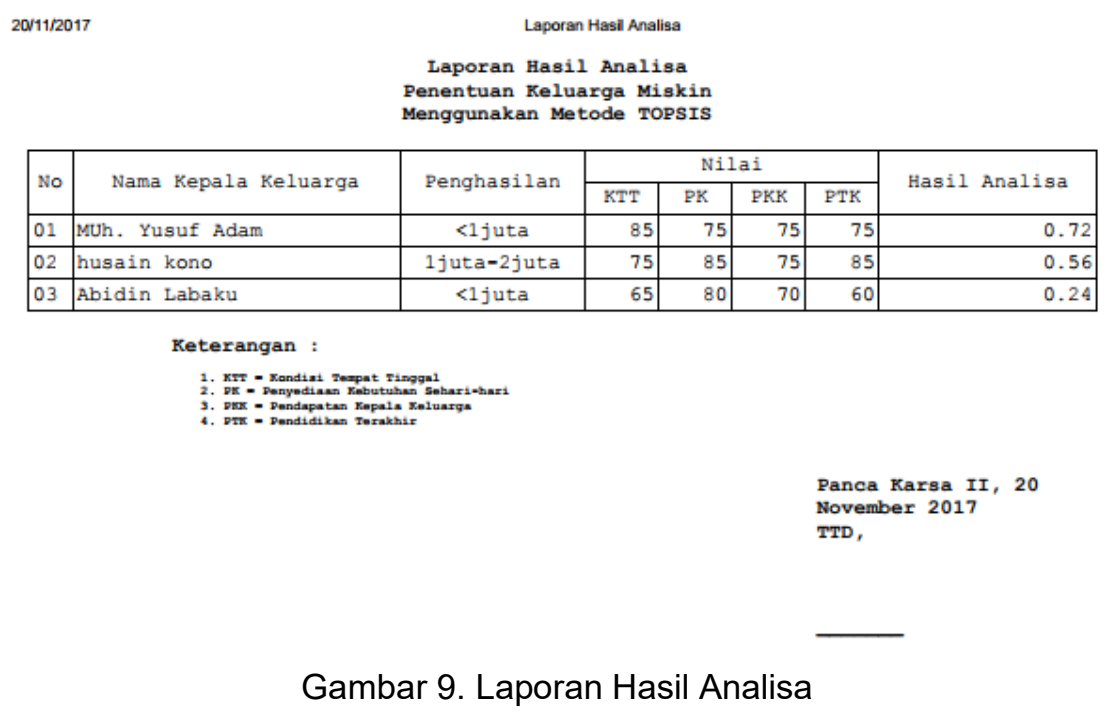

Pada form ini, digunakan untuk menampilkan laporan hasil analisa penentuan keluarga miskin menggunakan metode TOPSIS, dimana hasil yang ditampilkan diurutkan berdasarkan yang data masyarakat paling miskin.

\section{Kesimpulan dan Saran}

\subsection{Kesimpulan}

Berdasarkan hasil perancangan Penerapan Metode TOPSIS untuk sistem pendukung keputusan Penentuan Keluarga Miskin pada Desa Panca Karsa II maka dapat ditarik kesimpulan sebagai berikut:

1. Sistem yang digunakan pada mampu mengatasi kelemahan-kelemahan yang terdapat pada sistem yang lama dan memberikan hasil yang akurat dalam penentuan Keluarga Miskin

2. Penerapan Metode TOPSIS untuk sistem pendukung keputusan dapat memberikan hasil yang maksimal dalam hal pengambilan keputusan dengan cara mengurutkan alternatif masyarakat miskin mulai dari yang termiskin.

3. Berdasarkan hasil pengujian white box disimpulkan bahwa sistem pendukung keputusan ini bebas dari kesalahan program dengan total Cyclomatic Complexity $=6$, Region $=6$, dan Independent Path $=6$.

\subsection{Saran}

Sistem ini belumlah sempurna sehingga membutuhkan pengembangan yang lebih lagi, adapun saran dari penulis yaitu :

1. Untuk pengembangan penelitian lebih lanjut maka sebaiknya dilakukan perbandingan metode atau penggabungan metode.

2. Sebaiknya dilakukan backup data secara berkala demi keamanan sistem ini

\section{Daftar Pustaka}

[1] Rianto. 2008. Sistem pendukung keputusan penentuan keluarga miskin untuk prioritas penerima bantuan menggunakan metode analytic hierarchy process :: Studi kasus Pedukuhan Bulu RT 07, Trimulyo, Jetis, Bantul. Yogyakarta : Universitas Gadja Mada

[2] Profil Desa. 2016. Desa Panca Karsa II Kecamatan Taluditi Kabupaten Pohuwato

[3] Atmaja, Zenna dkk. 2012. Sistem Pendukung Keputusan Penentu Keluarga Miskin Metode AHP Berbasis Web Dinamis Study Kasus Kelurahan Ketaon, Banyudono, Boyolali. Jurnal TIKomSiN ISSN : 2338-4018

[4] Vercellis, Carlo. 2009. Business Intelligence: Datamining and Optimization For Decision Making. Chichester : Jhon Wiley \& Sons

[5] Kusumadewi, S., Hartati, S., Harjoko, A., Wardoyo, R. 2006. Fuzzy Multi Atribut Decision Making (FUZZY MADM), Graha Ilmu, Yogyakarta

[6] Dinas Sosial Kabupaten Pohuwato. 2016. Kriteria Keluarga Miskin. Pohuwato 